\title{
THE SIGNIFICANCE OF DIGITAL COMPETENCES OF UNIVERSITY TEACHERS: THE VIEWS OF THE TEACHERS AND STUDENTS THEMSELVES
}

\author{
Milan Chmura, Josef Malach and Dana Vicherková \\ Department of Education and Adult Education \\ University of Ostrava, Frani Sramka 3, Ostrava, the Czech Republic, 70900
}

\begin{abstract}
This study brings the results of an international study of the views of academic teachers (academics) and students from the Czech Republic, Poland, the Slovak Republic, and the Ukraine on the importance of the digital competence of academics. Digital competence is usually intertwined into a broader didactic competence that can be incorporated into the educational profile of an academic. Aggregated data in the first half of 2018 was compiled using statistical procedures for a group of academics, a group of students, and between both groups in each country, as well as across a multinational set. They point to differences and the consensus in perceiving the importance of digital components that can be used for the targeted further education of academics, setting up a system for the evaluation of studies, and for innovation in the university digital environment.
\end{abstract}

\section{KEYWORDS}

Digital Competence, Competency Model, University Teacher

\section{INTRODUCTION}

Both university teachers and students implement educational processes together that are currently strongly influenced by digital technologies. For many years, there has been an electronic learning environment in which both parties are located, and they are constantly learning how to use modern ICT to improve the pedagogical process. Both academics and students have to orient themselves in various electronic learning systems, and know how to use them.

The designation used to name an electronic learning environment varies considerably, which may, on the one hand, express its developmental phases, potential, or even realistic functionalities. E-learning environments (ELE) are associated with LMS Moodle, which has the ability to store study material files, realize teacher-student communication, as well as student-to-student communication, plan learning, assign and evaluate tasks, evaluate other students, testing, saving study results, etc. Some authors use Virtual learning environments (VLE) or Institutional Learning Environments (ILE). In the case of so-called "smart learning environments" (SLE), this is a targeted achievement of a synergy between pedagogy (pedagogues) and technologies. Pedagogy is represented in a smart environment by educational paradigms, social paradigms, assessment paradigms, social factors, and politics. The technology includes emerging technologies, innovative uses of mature technologies, adoption of usability and standards, and emerging/new technological paradigms (open educational resources)

Hwang (2014) summarizes the potential benefits of SLE in three respects: “(1) A smart learning environment is context-aware; i.e. the learner's situation or the contexts of the real-world environment in which the learner is located are sensed, implying that the system is able to provide learning support based on the learner's online and real-world status. (2) A smart learning environment is able to offer instant and adaptive support to learners by analyzing the needs of individual learners from different perspectives (e.g. learning performance, learning behaviours, profiles, personal factors) as well as the online and real-world contexts in which they are located. Moreover, it can actively provide a variety of personalized support to learners, including learning guidance, feedback, hints, and learning tools, based on their actual needs. (3) A smart learning environment is capable of adapting the user interface and the content to suit the personal factors (e.g. learning styles and preferences) and learning status of the individual learners. The user interface is not necessarily a conventional computer. Instead, learners can interact with the learning environment via mobile 
devices (e.g. smartphones or tablet computers), wearable devices (e.g. Google Glass or a digital wristwatch), or even ubiquitous computing systems embedded in everyday objects. Therefore, it is a challenging issue to adapt the user interface to meet learners' needs in a smart learning environment."

Education and learning use a variety of approaches to ICT applications and the personal learning environment (PLE). According to Schaffert and Hilzensauer (2008) PLE systems, in contrast to traditional Learning Management Systems (LMS), have met with great success, and are well on the way towards changing the learning and teaching paradigms.

Hénard and Roseveare (2012) show that there are significant changes in the concepts of teaching and learning at universities. In connection with the use of digital technologies, this especially concerns new relationships in terms of access to teachers and a broader range of communication and collaborative work through learning platforms, in terms of continuous upgrading in pedagogy, use of technology, and assessment models aligned with student-centred learning.

The status and use of information technology in higher education appears to be important, and in some cases, even necessary, as can be seen from the international FP7 research carried out by IRNet ${ }^{1}$. An international research team, made up of nine European universities plus Australia, conducted the following research in 2014-2015, focusing on the development, use, and evaluation of information and communication technologies for students and academics.

The first of these studies was focused on determining the level of information, communication, intercultural, and technological competences of Polish and Czech students gained during university studies. Self-assessment results from both countries, focusing on information and communication skills, show the need to use modern digital tools within the study (Gajdzica, Ogrodzka-Mazur, Chmura \& Malach, 2015).

The second study focused on the use of the e-learning environment and its contribution to higher education. Research has shown that students from the Czech Republic are more likely to use the Internet as a source of information than students from Poland. University teachers encourage their students to use electronic information resources, which contributes to the improvement of the level of digital literacy of university students, which is necessary in their future professional life (Malach, Kostolánová, Chmura, SzafrańskaGajdzica \& Ogródska-Mazur, 2015).

The subject of the third study was the use of social media by students from the Czech Republic and Poland as part of their university education. It has been found that social media is becoming increasingly important in the university environment, as it is an effective means of communicating within the university itself, between universities and their surroundings, and between teachers and students. The positive effects of social networks can be seen in learning outcomes, social integration, information sharing, and student adaptation to the university environment. A third of students use this form of media to present their own study assignments. Czech students appear to be more individualistically oriented, while Polish students are more likely to work together to solve tasks (Kostolányová, Malach \& Chmura, 2015).

The results of the fourth study, directed at academic staff, showed that university teachers use a number of electronic instruments for the implementation of education, the management of students' self-study and study communication to enhance the elements of online distance learning. Its actual choice or potential preferences are not much influenced by teachers' age but rather by their user level of ICT competence and in some cases also by their involvement in social networks (Ogrodzka-Mazur, Szafrańska, Malach \& Chmura, 2017).

\section{DIGITAL COMPETENCE OF ACADEMICS IN COMPETENT MODELS}

The digital competence of a university teacher has gradually made its way into the competency model of an academic worker. Today, electronic data processing, Internet communication, and the creation of digital learning content are commonplace. These activities are part of various competence models of academic staff.

As an example, we can present several competency models as seen by the Czech and foreign professional public. Bajtoš (2013) defines the components of the professional competencies of the university teacher, and differentiates them from the subject-matter (knowledge of the content of the curriculum), scientific (the ability to perform scientific research in his field), psycho didactic (creating favourable conditions for teaching), communication, organizational, counselling, self-reflective, and self-motivating. Approaches and opinions on the professional competences of a university teacher are rather diverse, and some authors present other specific components. ${ }^{1}$ International Research Network for Study and Development of New Tools and Methods for Advanced Pedagogical Science in the Field
of ICT Instruments, E-learning and Intercultural Competences (PIRSES-GA-2013-612536). 
Blašková, Blaško \& Kucharčíková (2014) present a competency model of a university teacher, which consists, in addition to the abovementioned, also from moral-ethical, technical, scientific, and didactic competences. It is also necessary for a university teacher to be a recognized author, a model for others, and to have excellent critical thinking, communication skills, and motivational skills.

In connection with the introduction of ICT into education and the use of e-learning courses, Jans \& Awouters (2009) mention ICT-competencies for teachers who work with these tools. ICT competences for teachers are summed up in three dimensions. "(1) The teacher knows what learning ICT activities can be set in (awareness). (2) The teacher has the necessary skills to use hardware and software (readiness) (3) The teacher knows the pedagogical-didactical elements of ICT (e.g. drill and practice programmes)".

In order to create a model for the digital competences of a university teacher and their subsequent development, the DigCompEdu (Digital Competence of Educators) may be used as an appropriate model. This material, in which the teacher's digital competences are newly described, was created by the Joint Research Center of the European Commission, with the Czech Republic also participating in international meetings of experts. The publication describes 22 teacher competences, divided into six areas: professional engagement, digital resources, teaching, digital assessment, pupil support, and student support for digital competences. The publication also highlights the possibility of gradual development of a digital competency teacher from level A1 (novice or beginner) to C2 level (pioneer) (Neumajer, 2018), (Redecker, 2017).

\section{RESEARCH ON RELEVANCE OF THE DIGITAL COMPETENCE OF ACADEMICS}

This study came about as part of the Visegrad fund grant project at the Faculty of Education of the University of Ostrava, entitled "High school teacher competence in change" ID No. 21720008 in 2017-2018. The Polish University of Silesia and Katowice also participated in the project solution, along with Slovakia (Matej Bel University), and the Ukraine (Ukrainian Academy of Acmeology\&BGKU).

\subsection{The Research Focus and Goal}

The subject of the research was the views of academics and university students (hereinafter referred to as "students") on the relevance of the professional competencies of academics. The research problem was the answer to the questions; Which professions are preferred or underestimated, by academics and students?; Whether and to what extent is there a perceived relevance of competencies, respectively, professional profiles matches between academics and students? The aim of the survey was to find out the current state of opinion of academics and students on the importance of professional competences and profiles for pursuing the professions of an academic at a selected university, to identify differences of opinion on competencies in each of the groups studied, and to assess the degree of consensus of opinion on the individual competencies of academics and students.

\subsection{Method}

The questionnaire method was selected as a research tool. The questionnaire was compiled by the University of Borys Grinchenko University in Kiev, and was subsequently modified on the basis of the input from teams from partner countries. Different competencies were surveyed with up to four items in the questionnaire, which had a total of 37 closed scalar items, with four answer options (1-definitely yes, 2-yes, 3-no, 4-definitely not), one open (finding specific characteristics that are important for academics' activities), and several items identifying gender, age, length of practice, and academic rank among academics, and gender, age, and academic year of students. The individual competencies are divided into three profiles: Professional-pedagogical, social-personnel, and academic (scientific). The Professional-pedagogical profile includes competencies C1.1: Innovative (Items 9, 13), C1.2: Professional self-improvement (Items 1, 5, 14), C1.3: Digital (Items 2, 3, 7), C1.4: Communicative-interactive (Items 4, 10), and C1.5: Management (Items 6, $8,11,12)$. The individual items in the questionnaire for the relevant competencies are shown in Table 1 . The items 2,3 , and 7 were used for the examined digital competences, which encapsulated the digital competences, and were assigned item No. 4, which was incorporated into the communicative-interactive competence. The used items are highlighted in bold in Table 1. 
Table 1. Profile 1 - Professional-Pedagogical

\begin{tabular}{|c|c|c|}
\hline Item code & Competence & Items in the questionnaire \\
\hline 1 & $\mathrm{C} 1.2$ & Continuous own improvement, improving specific and professional level \\
\hline 2 & C1.3 & Introducing innovative teaching methods including utilization of ICT \\
\hline 3 & C1.3 & Work, bound on critical analysis, with information from international databases \\
\hline 4 & C1.4 & Using various types of communication with students and colleagues, including ICT \\
\hline 5 & $\mathrm{C} 1.2$ & $\begin{array}{l}\text { Utilization of the fundamental knowledge in an educational process and achievements of } \\
\text { modern science, constantly updating the content of taught courses }\end{array}$ \\
\hline 6 & $\mathrm{C} 1.5$ & $\begin{array}{l}\text { Creating the educational environment with support of student's cognitive activity and } \\
\text { research }\end{array}$ \\
\hline 7 & C1.3 & Creating the courses based on the distance education \\
\hline 8 & $\mathrm{C} 1.5$ & Ability to using methods focused on control of student's independent study \\
\hline 9 & $\mathrm{C} 1.1$ & Flexibility, enterprising and initiative in professional activities \\
\hline 10 & $\mathrm{C} 1.4$ & $\begin{array}{l}\text { Classification of an interactive coordinated work with students as the most effective type } \\
\text { of education; organization of group and collective project activities }\end{array}$ \\
\hline 11 & $\mathrm{C} 1.5$ & $\begin{array}{l}\text { Ability to proposal and achievement of didactical aims using the SMART method } \\
\text { ( } \mathrm{S} \text { - specific, } \mathrm{M} \text { - measurable, } \mathrm{A} \text { - achievable, } \mathrm{R} \text { - relevant, } \mathrm{T} \text { - time-bound) }\end{array}$ \\
\hline 12 & $\mathrm{C} 1.5$ & Application and modification of various methods for monitoring educational results \\
\hline 13 & C1.1 & Positive approaches to reforms and changes occurring in higher education \\
\hline 14 & $\mathrm{C} 1.2$ & Satisfaction with results of own professional activities \\
\hline
\end{tabular}

\subsection{Research Set}

A total of 993 respondents participated in the survey, of which 328 were academics, and 665 were students from the above countries. From the Czech Republic, answers were received from 73 academics and 150 students, from Slovakia (always in the same order) 65 and 83 responses, from Poland 63 and 164 responses, and from the Ukraine 125 and 269 responses.

\subsection{Descriptive Results}

Table 2 lists the results of descriptive statistics in the form of arithmetic averages for groups of academics and students on the issue in question. In the questionnaire, the attitude level was expressed in an interval with the following values: 1 (Yes), 2 (Probably yes), 3 (Probably not) and 4 (No).

Table 2. Arithmetical Averages for Items Forming Digital Competences

\begin{tabular}{clccccc}
\hline Country & Respondent & $2^{\text {nd }}$ Item & $3^{\text {rd }}$ Item & $4^{\text {th }}$ Item & $7^{\text {th }}$ Item & All Items \\
\hline \multirow{2}{*}{ Czech } & Academics & 1.58 & 1.89 & 1.48 & 2.08 & 1.75 \\
Republic & Students & 1.70 & 1.93 & 1.43 & 2.10 & 1.79 \\
\hline \multirow{2}{*}{ Poland } & Academics & 2.06 & 2.41 & 1.73 & 2.87 & $\mathbf{2 . 2 6}$ \\
& Students & 1.90 & 1.95 & 1.65 & 2.10 & $\mathbf{1 . 9 0}$ \\
\hline \multirow{2}{*}{ Ukraine } & Academics & $\mathbf{1 . 4 4}$ & $\mathbf{1 . 6 1}$ & $\mathbf{1 . 3 0}$ & $\mathbf{2 . 0 0}$ & $\mathbf{1 . 5 8}$ \\
& Students & $\mathbf{1 . 4 1}$ & $\mathbf{1 . 5 3}$ & $\mathbf{1 . 3 7}$ & $\mathbf{1 . 5 8}$ & $\mathbf{1 . 4 7}$ \\
\hline \multirow{2}{*}{ Slovakia } & Academics & 1.66 & 1.67 & 1.60 & 2.49 & 1.85 \\
& Students & 1.56 & 2.00 & 1.57 & 2.54 & $\mathbf{1 . 9 1}$ \\
\hline \multirow{2}{*}{ Countries of } & Academics & 1.69 & 1.90 & 1.53 & 2.36 & 1.87 \\
Visegrad & Students & 1.64 & 1.85 & 1.51 & 2.08 & 1.77 \\
\hline
\end{tabular}


By comparing the arithmetic mean of the individual items, it is clear that academics and students from the Ukraine attribute the greatest importance to the academic competence of academics. This result was shown both for individual items and overall. The least relevant is digital competence for academics from Poland, and students from Slovakia and Poland. The values listed in Table 2 are shown in bold.

\subsection{Results of Testing Hypotheses}

In the quantitative research, hypotheses were defined. Hypotheses were focused on testing the existence, respectively the non-existence, of the statistical significant differences in each. In the hypotheses, the classification based on academics and students was considered. Each hypothesis was bound with a concrete question from the questionnaire. The significance level was declared as 5\%, respectively $0.05 \%$. For each defined hypothesis, testing the normality of data was realized using the Shapiro-Wilk and Anderson-Darling tests on the significance level $0.05 \%$. With respect to achieved results of those testing normality, the Kruskal-Wallis test had to be used for testing the defined hypotheses.

Testing hypotheses was realized in the statistical software PAST Statistics, version 2.17 (Hammer, et. al., 2001). Obtained results of testing hypotheses can be seen in Table 3. If $\mathrm{p}<0.05$, then the zero hypothesis was rejected in favour of the alternative hypothesis. In opposite cases, the zero hypothesis was failed to be rejected.

Table 3. Testing Hypotheses on Significant Differences between Approaches of Academics or Approaches of Students across Visegrad Countries

\begin{tabular}{cccc}
\hline & & $p$ value of Testing & Signif. \\
Respondents & Items & Hypothesis & Differences \\
\hline \multirow{2}{*}{ Academics } & $2^{\text {nd }}$ Item & $7,342 \mathrm{E}-07$ & Yes \\
across Visegrad Countries & $3^{\text {rd }}$ Item & $9,106 \mathrm{E}-10$ & Yes \\
& $4^{\text {th }}$ Item & $5,877 \mathrm{E}-05$ & Yes \\
& $7^{\text {th }}$ Item & $5,701 \mathrm{E}-13$ & Yes \\
\hline Students & $2^{\text {nd }}$ Item & $1,970 \mathrm{E}-12$ & Yes \\
across Visegrad Countries & $3^{\text {rd }}$ Item & $8,742 \mathrm{E}-13$ & Yes \\
& $4^{\text {th }}$ Item & $2,776 \mathrm{E}-05$ & Yes \\
& $7^{\text {th }}$ Item & $2,923 \mathrm{E}-22$ & Yes \\
\hline
\end{tabular}

Based on the statistical testing of the differences in the Visegrad group of academics and in the group of students across the Visegrad countries, we can state that in all of the items of the questionnaire, statistically significant differences were found among the opinions. The views of academics of the transnational group on the significance of partial activities that create digital competences, i.e. in fields: 2 Introduction of innovative teaching methods including the use of ICT, 3 Work, bound on critical analysis, with information from international databases, 4 Using different types of communication with students and colleagues, including ICT, and all courses are different from each other. Also, the opinions of the students of the transnational group, on the significance of the partial activities that create the digital competences, are different in all of the items.

Within the framework of ICT competencies, in Table 4, obtained results of testing hypotheses on existence statistical significant differences between approaches of academics and students in each country, resp. in all countries of Visegrad, can be seen. 
Table 4. Testing Hypotheses on Significant Differences between the Approaches of Academics and the Approaches of Students in Each Country, resp. in Countries of Visegrad

\begin{tabular}{cccc} 
Countries & Considered Approach & $\begin{array}{c}p \text { value of Testing } \\
\text { Hypothesis }\end{array}$ & $\begin{array}{c}\text { Signif. Differences } \\
\text { Yes/Not }\end{array}$ \\
\hline \multirow{4}{*}{ Czech Republic } & $2^{\text {nd }}$ Item & 0.2167 & Not \\
& $3^{\text {rd }}$ Item & 0.7242 & Not \\
& $4^{\text {th }}$ Item & 0.855 & Not \\
& $7^{\text {th }}$ Item & 0.5988 & Not \\
\hline \multirow{4}{*}{ Poland } & $2^{\text {nd }}$ Item & 0.1089 & Not \\
& $3^{\text {rd }}$ Item & $9.95 \mathrm{E}-5$ & Yes \\
& $4^{\text {th }}$ Item & 0.4093 & Not \\
& $7^{\text {th }}$ Item & $1.2 \mathrm{E}-7$ & Yes \\
\hline \multirow{5}{*}{ Ukraine } & $2^{\text {nd }}$ Item & 0.287 & Not \\
& $3^{\text {rd }}$ Item & 0.1688 & Not \\
& $4^{\text {th }}$ Item & 0.417 & Not \\
& $7^{\text {th }}$ Item & 0.003 & Yes \\
\hline \multirow{3}{*}{ Slovakia } & $2^{\text {nd }}$ Item & 0.2688 & Not \\
& $3^{\text {rd }}$ Item & 0.007 & Yes \\
& $4^{\text {th }}$ Item & 0.639 & Not \\
& $7^{\text {th }}$ Item & 0.77 & Not \\
\hline \multirow{5}{*}{ Countries of Visegrad } & $2^{\text {nd }}$ Item & $2.06 \mathrm{E}-16$ & Yes \\
& $3^{\text {rd }}$ Item & $1 \mathrm{E}-19$ & Yes \\
& $4^{\text {th }}$ Item & $8.08 \mathrm{E} 8$ & Yes \\
& $7^{\text {th }}$ Item & $7.85 \mathrm{E}-35$ & Yes \\
\hline
\end{tabular}

Table 4 shows that:

a) there are no statistically significant differences between the opinions of academics and students in the Czech Republic

b) in Poland and Slovakia, there are statistically significant differences between the opinions of academics and students on the activities mentioned in Item 3. In Poland, students consider this activity to be more significant than academics, and vice versa, while in Slovakia, they perceive it as more significant than students.

c) In the Ukraine, the opinions of academics differ considerably from students' views on the importance of the activity mentioned in section 7 , which perceives this activity of academics as more important than the academics themselves.

d) the views of all academics of the Visegrad transnational group are statistically significantly different in all four items from those of all students in the Visegrad transnational group.

\section{DISCUSSION}

The research survey, upon which the results of this study are based, was not only aimed at examining the views of academics and students on the importance of the activities of the academic staff falling within its digital competence, but also dealt with the complex of their work activities, differentiated into three professional profiles, and within them, 14 professional competencies. The research tool-questionnaire therefore contained significant, but not all, activities that would create a complete and comprehensive digital competence for the academic. While this is not yet defined, it can still be derived from the newly formulated digital competences 
of educators, such as DigCompEdu, ISTE (International Society for Technology in Education), or UNESCO's Computational Teachers' Framework ("ISTE Standards Teachers", 2008), (UNESCO, 2011).

Despite the limitation of this study, the present research results can be considered to be an up-to-date picture of the views of academics and university students on the importance of key activities of academics in the field of digital media applications for higher education learning environments in neighbouring European countries. Other intended investigations will already focus on digital competency, and will allow more accurate determination of the significance of other components of digital literacy of academics, and subsequently analyze the true state of their actual development.

\section{CONCLUSION}

Digital competences are increasingly more important professional prerequisites for current academics in all countries. For their continued development in line with technical and pedagogical innovations, there may be compelling evidence of the importance of individual academics and their students. Research data obtained from almost a thousand respondents in four countries showed that the arithmetic averages calculated from the subjective relevance of the activities of academics in the field of digital applications varied in all ten sets, between 1.37 and 2.54, meaning that the respondents expressed their full agreement, or rather a consensus, as opposed to a disagreement with the claims made, which included the four monitored components of the academic competence of the academic. These findings can be considered to be "prodigious" attitudes of academics and students, and these should be transported into evaluation tools for the assessment of higher education and learning. The use of digital technologies, as recently revealed by another recent study, (Malach \& Malachová, 2018), is still under-reflected in the student assessment of university education.

\section{ACKNOWLEDGEMENT}

The present study originated as part of a grant research project of the Visegrad Fund at Faculty of Education, University of Ostrava entitled "High school teacher competence in change", ID No. 21720008, in the years 2017 to 2018. Partner universities from the Ukraine, Poland, and Slovakia co-operated on the project.

\section{REFERENCES}

Bajtoš, J. (2013). Didaktika vysokej školy. Bratislava: Iura Edition.

Blašková, M., Blaško, R., \& Kucharčíková, A. (2014). Competences and Competence Model of University Teachers [Online]. Procedia - Social and Behavioral Sciences, vol. 159, 457-467. https://doi.org/10.1016/j.sbspro.2014.12.407

Gajdzica, A., Ogrodzka-Mazur, E., Chmura, M., \& Malach, J. (2015). Research Into Students' ICT Competencies and Their Use in ICT at Selected Universities. A Polish - Czech Comparative Study. Studia Edukacyjne, vol. 36, 365-379. https://doi.org/10.14746/se.2015.36.21

Hénard, F., \& Roseveare, D. (2012). Fostering Quality Teaching in Higher Education: Policies and practices. OECD: Guide for Higher Education Institutions.

Hwang, G. (2014). Definition, framework and research issues of smart learning environments - a context-aware ubiquitous learning perspective. Smart Learning Environments, vol. 1(issue 1). https://doi.org/10.1186/s40561-014-0004-5

ISTE Standards Teachers [Online]. (2008). International Society for Technology in Education. ISTE: ISTE. Retrieved from https://www.iste.org/docs/pdfs/20-14_ISTE_Standards-T_PDF.pdf

Jans, S., \& Awouters, V. (2009). E-learning Competencies for Teachers in Secondary and Higher Education. International Journal of Emerging Technologies in Learning (iJET), vol. 4 (issue 2), pp. 58-60. https://doi.org/10.3991/ijet.v4i2.739

Kostolányová, K., Malach, J., \& Chmura, M. (2015). Social Media as a Means of University Study Support. In Information and Communication Technology in Education: Proceedings of the 2015 ICTE 2015 (pp. 41-53). Ostrava: University of Ostrava.

Malach, J., Kostolánová, K., Chmura, M., Szafrańska-Gajdzica, A., \& Ogródska-Mazur, E. (2015). ICT-Supported Education at Czech and Polish Universities: A Comparative Study [Online]. International Journal of Information and Communication Technologies in Education, vol. 4(issue 4), 48-68. https://doi.org/10.1515/ijicte-2015-0019 
Malach, J., \& Malachová, K. (2018). Trends and Strategies in ICT Application in Higher Education versus Evaluation of Teaching and Learning. In M. Turčány, Z. Balogh, M. Munk, J. Kapusta \& L. Benko, DIVAI 2018 12th International Scientific Conference on Distance Learning in Applied Informatics (pp. 313-324). Štúrovo: Conference Proceedings Štúrovo, Slovakia May 2 - 4, 2018.

Neumajer, O. (2018). Rámce digitálních kompetencí učitele. Řizení školy: Letní speciál, 15(7-8), 7-8.

Ogrodzka-Mazur, E., Szafrańska, A., Malach, J., \& Chmura, M. (2017). The Use of E-learning Resources by Academic Teachers - a Polish- Czech Comparative Study. The New Educational Review, 2017(4), 169-185. https://doi.org/10.15804/tner.2017.50.4.14

Redecker, C. (2017). European Framework for the Digital Competence of Educators: DigCompEdu. European union: Joint Research Centre.

Schaffert, S., \& Hilzensauer, W. (2008). On the way towards Personal Learning Environments: Seven crucial aspects. eLearning Papers, 9(7), 1-11.

UNESCO, . (2011). UNESCO ICT Competency Framework for Teachers [Online]. France: UNESCO and Microsoft. Retrieved from https://unesdoc.unesco.org/ark:/48223/pf0000213475 